\title{
MINERAL CHEMISTRY AND FORMATION OF AWARUITE AND HEAZLEWOODITE IN THE XEROLIVADO CHROME MINE, VOURINOS, GREECE
}

\author{
Tzamos E. ${ }^{1}$, Filippidis A. ${ }^{1}$, Michailidis K. ${ }^{1}$, Koroneos A. ${ }^{1}$, Rassios A. ${ }^{2}$, Grieco \\ G. ${ }^{3}$, Pedrotti M. ${ }^{3}$ and Stamoulis K. ${ }^{4}$ \\ ${ }^{1}$ Aristotle University of Thessaloniki, Faculty of Sciences, School of Geology, Department of \\ Mineralogy-Petrology-Economic Geology, 541 24, Thessaloniki, Greece, tzamos@geo.auth.gr, \\ anestis@geo.auth.gr,kleopas@geo.auth.gr,koroneos@geo.auth.gr \\ ${ }^{2}$ Institute of Geology and Mineral Exploration, Lefkovrisi, Kozani, 501 00, Kozani, Greece, \\ rassannie@gmail.com \\ ${ }^{3}$ Department of Earth Sciences, Università degli Studi di Milano, Via Botticelli, 23, Milano, Italy, \\ giovanni.grieco@unimi.it, maria.pedrotti84@gmail.com \\ ${ }^{4}$ Geologist, Kastania, Servia, 505 00, Kozani, Greece, stamoul@hotmail.gr
}

\begin{abstract}
The Serpentinite between the chromite bodies 4 and 5 of Xerolivado mine (Vourinos, Greece), contains sparsely very small grains $(<20 \mu m)$ of awaruite $\left(\mathrm{Fe}_{0.91} \mathrm{Cu}_{0.06} \mathrm{Co}_{0.03} \mathrm{Ni}_{3}\right)$, heazlewoodite $\left(\mathrm{Ni}_{2.91} \mathrm{Fe}_{0.06} \mathrm{~S}_{2}\right)$, magnetite and Co-pentlandite $\left(\mathrm{Ni}_{3.79} \mathrm{Fe}_{2.98} \mathrm{Co}_{2.38} \mathrm{~S}_{8}\right)$. The olivine contains $0.40 \mathrm{wt} \% \mathrm{NiO}$ and $6.91 \mathrm{wt} \% \mathrm{FeO}$, while the serpentine $0.18 \mathrm{wt} \% \mathrm{NiO}$ and $3.02 \mathrm{wt} \% \mathrm{FeO}$. The Co-content of awaruite is 1.31 $w t \%$ and that of heazlewoodite $0.12 \mathrm{wt} \%$. Heazlewoodite is a product of the primary Co-pentlandite reduction, resulting from the serpentinization of the ultramafic rock. The Ni content of awaruite is derived both from olivine and from Co-pentlandite. The reducing environment resulting from serpentinization and the low sulphur fugacity, favour the formation of awaruite, heazlewoodite and magnetite.
\end{abstract}

Keywords: Pentlandite, olivine, serpentine, magnetite.

\section{Пєрі́ $\eta \psi \eta$}

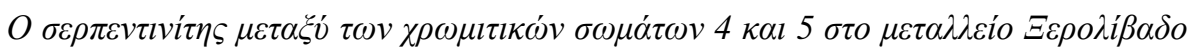

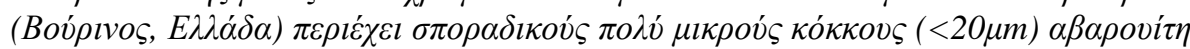

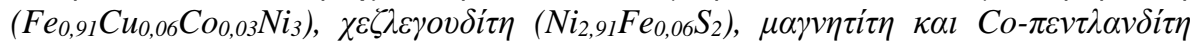

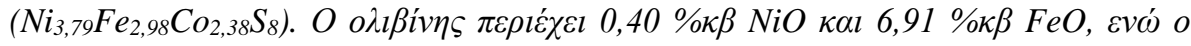

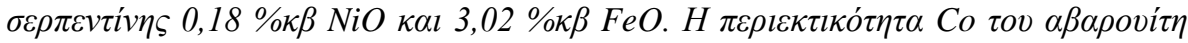

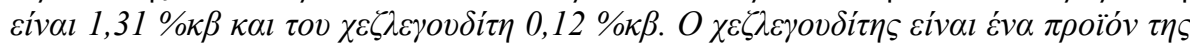

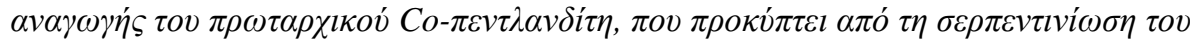

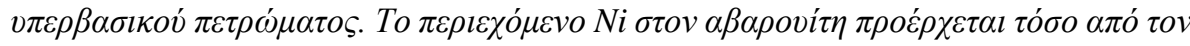

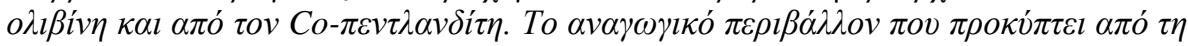

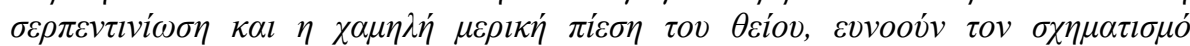

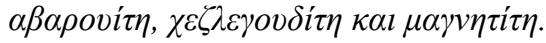

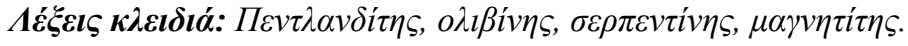




\section{Introduction}

The paragenesis and the chemical composition of the opaque minerals (e.g., sulphides, metal alloys) formed during serpentinization, depend on the initial chemical composition of the olivine and the oxygen and sulfur fugacities $\left(\mathrm{fO}_{2}\right.$ and $\mathrm{fS}_{2}$ ). The $\mathrm{Ni}^{2+}$ commonly display preference in the $\mathrm{M} 1$ site of olivine, and the serpentinized olivine is proposed as the source of nickel (Brown, 1980; Filippidis and Annersten, 1981; Annersten et al., 1982; Filippidis, 1982, 1985, 1991; Nord et al., 1982; Deer et al., 1997), whereas, the origin of the sulfur is attributed to the fluid phase that causes the serpentinization. The sulfur either exists in the fluid phase, or comes from sources outside of the ultramafic body and transferred by the fluid phase along with $\mathrm{H}_{2} \mathrm{O}, \mathrm{CO}_{2}$ and $\mathrm{Cl}$ (Ashley, 1973; Groves and Keays, 1979; Groves et al., 1979; Donaldson, 1981; Donaldson and Bromley, 1981; Seccombe et al., 1981; Pasteris, 1984).

The "internal" sulfur, which originates from magmatic sulphides, immigrates during serpentinization (Shima and Naldrett, 1975; Donaldson, 1981; Seccombe et al., 1981). Sulfur can occur under reducing conditions from these magmatic sulphides (e.g., pentlandite, pyrrhotite) with the process of desulfurization, producing $\mathrm{H}_{2} \mathrm{~S}$, sulphides and alloys at temperatures of $365-445^{\circ} \mathrm{C}$. The produced $\mathrm{H}_{2} \mathrm{~S}$, reacts with the metallic elements that are released during the serpentinization of the silicate minerals and Ni-Fe-sulphides are produced. Further serpentinization, can lead to the formation of violarite and/or millerite (Krishna Rao, 1964, Kanehira et al., 1975).

The maximum thermal stability of pentlandite is at the temperature of $610^{\circ} \mathrm{C}$, however pentlandites frequently contain amounts of $\mathrm{Co}$ substituting $\mathrm{Fe}$ and $\mathrm{Ni}$. The presence of Co raises the thermal stability of pentlandites (up to $630^{\circ} \mathrm{C}$ ) and the confining pressure reduces it to $425^{\circ} \mathrm{C}$. The maximum thermal stability of heazlewoodite is $556^{\circ} \mathrm{C}$, but metal deficiency lowers it to $524^{\circ} \mathrm{C}$ The $\mathrm{Ni}$ content of awaruite and heazlewoodite is interpreted as being derived both from primary silicates and from a primary sulphide such as pentlandite; under reducing conditions pentlandite is desulphurized (Craig and Scott, 1974).

The present study investigates the mineral-chemistry and formation of awaruite (Ni-Fe alloy) and heazlewoodite, found in the serpentinite of the Xerolivado chrome mine, Vourinos, Greece.

\section{Geologic setting}

The Vourinos ophiolite complex is located in western Macedonia of northern Greece (Fig. 1). It covers an area of $400 \mathrm{~km}^{2}$ dominated by mantle rocks and it constitutes a complete ophiolite sequence with a well-exposed petrologic moho (Grieco and Merlini, 2012). The crustal sequence consists of mafic and ultramafic cumulates, gabbro, dykes, pillow lavas and carbonate sediment cover (Liati et al., 2004; Rassios and Moores, 2006). The age of the Vourinos oceanic crust was found to be $168.5 \pm 2.4$ my and $172.9 \pm 3.9$ my via $\mathrm{U} / \mathrm{Pb}$ analyses of zircons within plagiogranite (Liati et al., 2004). Mantle rocks are strongly depleted and dominated by harzburgite with abundant irregular chromitite-hosting dunite bodies (Saccani et al., 2004; Bortolotti et al., 2004; Grieco and Merlini, 2012). Some areas, several close to the eastern emplacement margin, are serpentinized (Margaras and Vacondios, 1996, Grieco and Merlini, 2012).

Many authors have worked on Vourinos geological and petrological/geochemical characteristics and evidence confirms the existence of multiple magma chambers and that the harzburgites represent mantle residue, remaining after a high degree of partial melting (Moores, 1969; Jackson et al., 1975; Harkins et al., 1980; Beccaluva et al., 1984; Paraskevopoulos and Economou, 1986; Konstantopoulou and Economou-Eliopoulos, 1991). The chromite formation in dunite occurred at about $1300^{\circ} \mathrm{C}$ with re-equilibration at about $600^{\circ} \mathrm{C}$ (Rassios and Kostopoulos, 1990). The successive stages of the structural evolution and deformation of the chromite-hosting dunite bodies were: a) Dunite and chromite formation within the upper mantle, b) High-temperature plastic deformation resulting from mantle flow, c) Low-temperature plastic to semi-brittle deformation resulting in folding of dunite and chromite and d) Brittle deformation (faults and thrusts) displacing the dunites 
and chromite ore bodies (Ross et al., 1980; Roberts, 1988; Konstantopoulou, 1993; Filippidis, 1996, 1997; Grieco and Merlini, 2012). Serpentinization processes controlled the final mineralogical composition of the rocks and resulted in the serpentinization of the former dunite and its alteration to serpentinite and/or serpentinized peridotite.

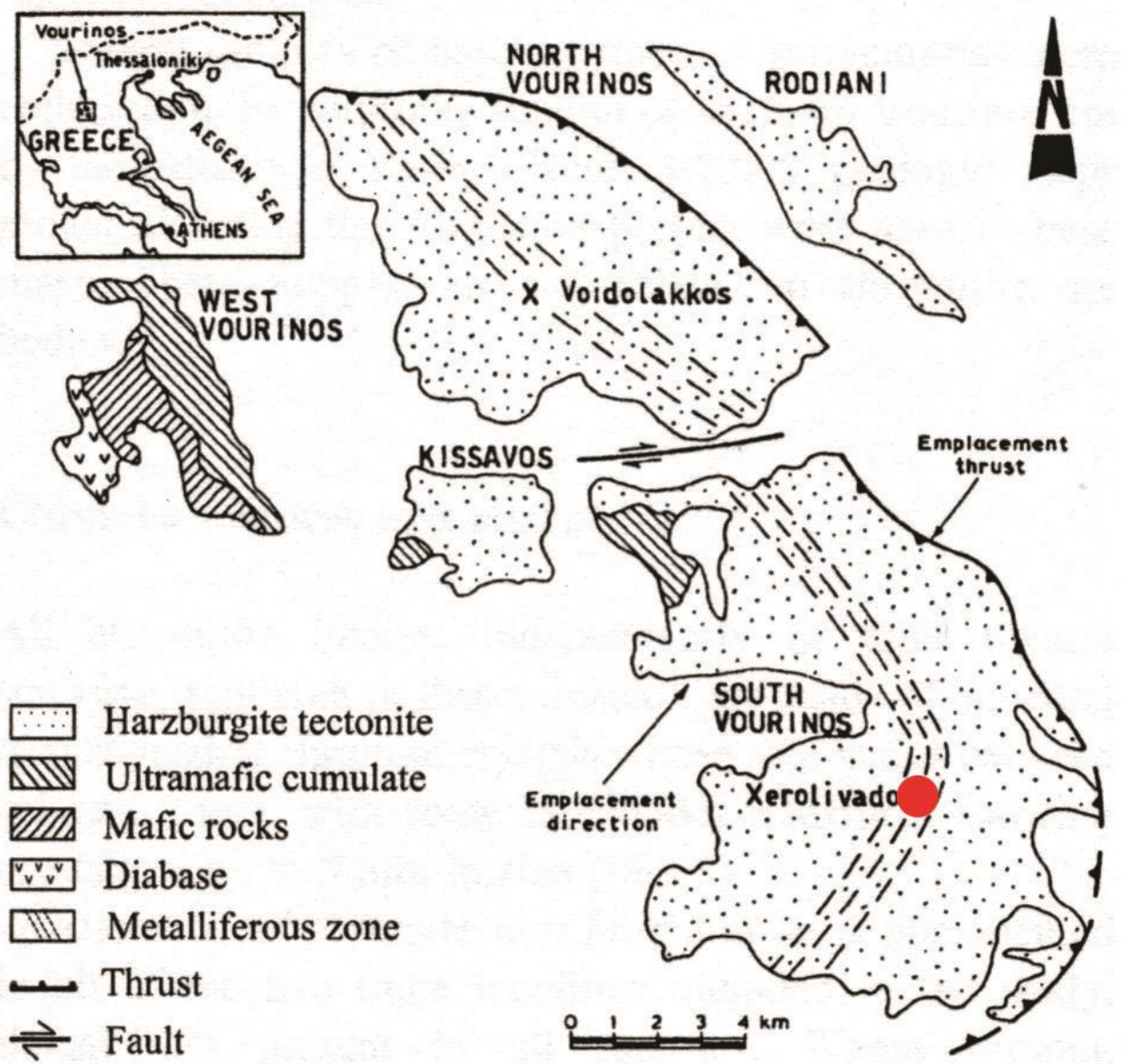

Figure 1 - Major petrologic units of the Vourinos ophiolite complex and location of the Xerolivado mine (red circle) (after Grivas et al., 1993).

The largest dunite body of Vourinos occurs at Xerolivado locality (Fig. 1). It has an approximate surface exposure of $3 \mathrm{~km}^{2}(3 \times 1 \mathrm{~km})$. Harzburgite tectonite hosts the dunite body but also outcrops within the dunite, occurring as elongated masses, with length up to $300 \mathrm{~m}$, striking NE-SW (Apostolidis et al., 1981; Roberts, 1988; Stamoulis, 1990; Filippidis, 1996, 1997). The Xerolivado chromite mine, hosted in the ultramafic body, is one of the world's largest alpine type chromite deposit, with a known potential of 6 million tons of schlieren ore averaging 22 modal percent chromite-schlieren chromitite bodies contain bands of schlieren ore, each being 1 to $15 \mathrm{~cm}$ thick, alternating with the ultramafic rock (Stamoulis, 1990; Filippidis, 1996).

Three main normal fault zones (F1, F2 and Fm) divide the Xerolivado mine into four sectors: the northern, the central, the southern and the southwestern (Fig. 2). These fault zones down throw the ultramafic body and the hosted chromitite bodies to the SW with horizontal and vertical dislocations (Stamoulis, 1990; Filippidis, 1996, 1997). The schlieren chromite bodies with thickness ranging between 1 and $12 \mathrm{~m}$ strike NE-SW and steeply dipping towards NW. 


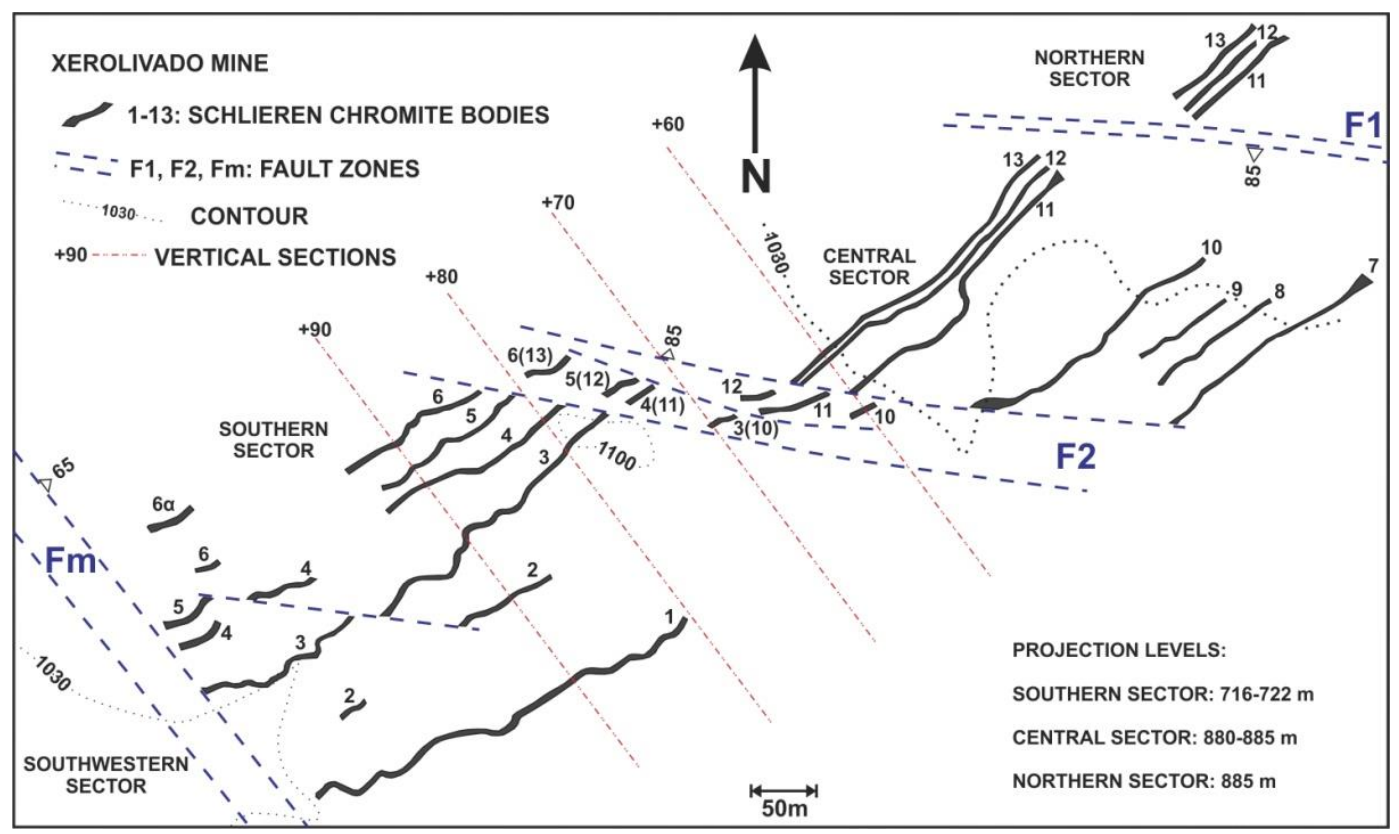

Figure 2 - Distribution and form of the schlieren chromite ore bodies of the Vourinos Xerolivado mine (modified after Filippidis, 1996).

\section{Materials and methods}

The serpentinite samples were collected from the underground tunnels of the Xerolivado chromite mine, between chromite bodies 4 and 5 (Fig. 2). Thin and thin-polished sections were mounted from these samples and they were investigated by optical microscopy, scanning electron microscope and electron microprobe for their textures as well as their mineralogical and chemical composition.

Mineral chemistry of sulphides and metal alloys was determined with a JEOL 8200 electron microprobe at the University of Milan. For the analyses the system was operated using an accelerating voltage of $15 \mathrm{kV}$, a sample current on brass of $15 \mathrm{nA}$ and a counting time of $20 \mathrm{~s}$ on the peaks and $10 \mathrm{~s}$ on background. A series of natural minerals were used as standards.

\section{Results}

The microscopic examination of the samples shows that they are dominated by the presence of serpentine. Modal analyses of the samples shows that presence of serpentine makes up more than $90 \% \mathrm{v} / \mathrm{v}$ of total silicates, thus all samples are characterized as serpentinites. Serpentine has a typical mesh texture, the position of the original fractures and grain boundaries of olivine are marked by a simple parting or by a string of magnetite, sulphides and metal alloys. Sulphides, magnetite and metal alloys grains are found disseminated in the serpentinite matrix having a relatively small size of no more than $20 \mu \mathrm{m}$ (Fig. 3). Awaruite and heazlewoodite are also found substituting primary pentlandite (Fig. 3b, c and d). Chromite is also present in disseminated grains. Some chromite grains are altered to ferrochromite in spots on their rims. 


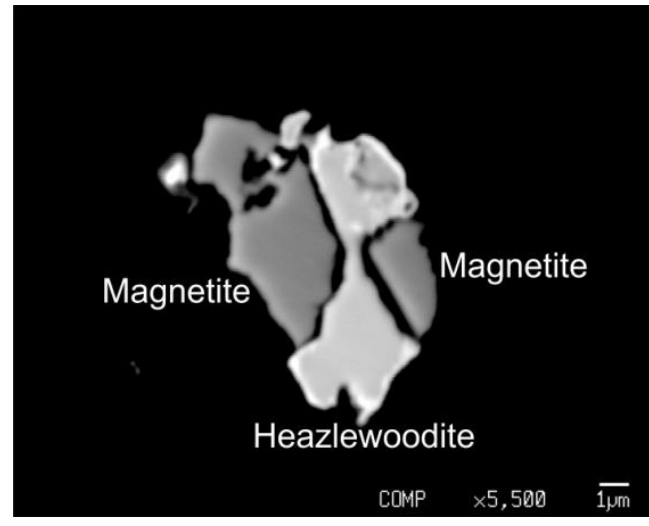

$\mathbf{a}$

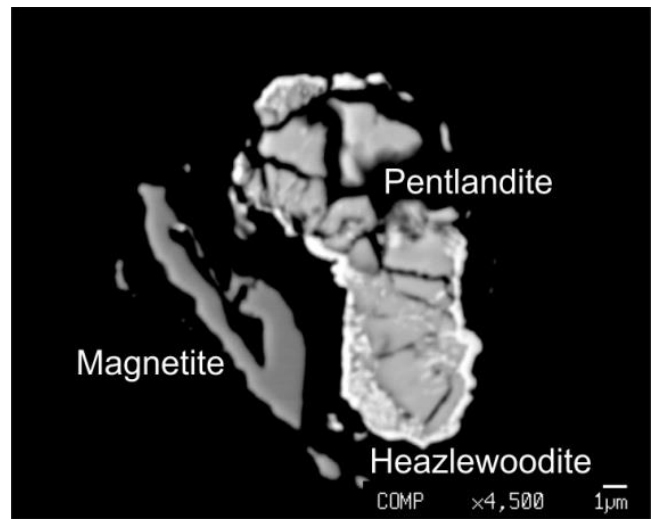

c

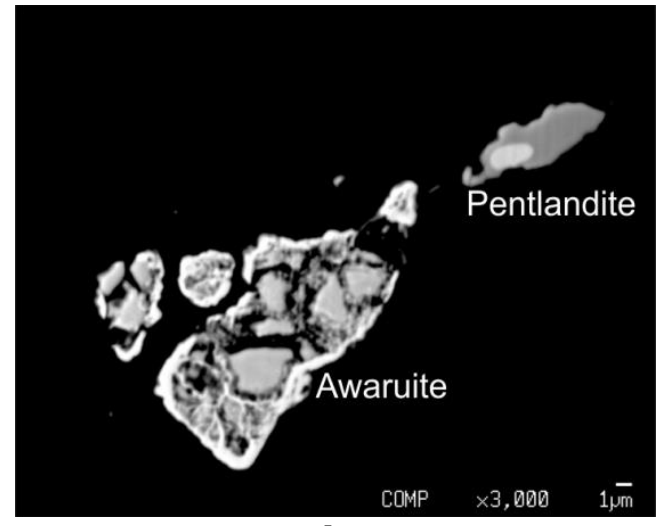

b

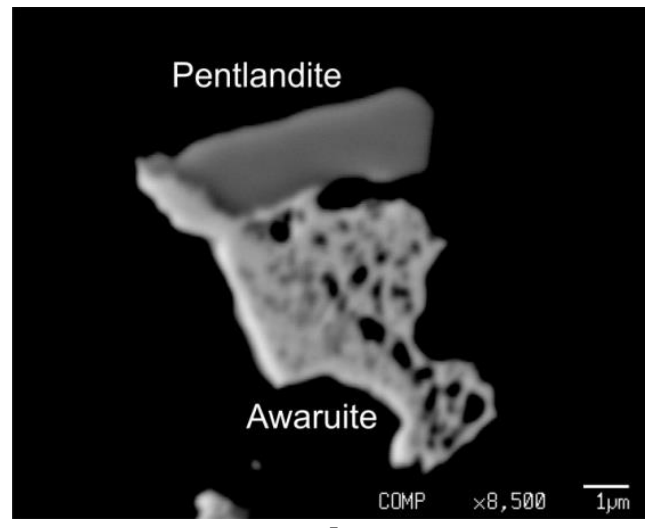

d

Figure 3 - Microphotographs from scanning electron microscope (SEM) with back-scattered electron image (BSI) from Xerolivado serpeninites. a) Sample D4-5/717, magnetite (gray) and heazlewoodite (light gray), b) Sample D4/765, awaruite (light gray) and pentlandite (gray), c) Sample D4-5/738, magnetite (gray), pentlandite (light gray) and heazlewoodite (white rim), d) Sample D4-5/765, awaruite (light gray) and pentlandite (gray).

The chemical compositions of awaruite, heazlewoodite, and pentlandite are presented respectively in Tables 1, 2, and 3.

Awaruite contains on average $75.71 \mathrm{wt} \% \mathrm{Ni}, 21.67 \mathrm{wt} \% \mathrm{Fe}, 1.53 \mathrm{wt} \% \mathrm{Cu}$ and $1.31 \mathrm{wt} \% \mathrm{Co}$ (Table 1). Heazlewoodite contains $71.32 \mathrm{wt} \% \mathrm{Ni}, 1.48 \mathrm{wt} \% \mathrm{Fe}$ and $0.12 \mathrm{wt} \%$ Co (Table 2). Pentlandite contains $28.14 \mathrm{wt} \% \mathrm{Ni}, 21.02 \mathrm{wt} \% \mathrm{Fe}$ and $17.71 \mathrm{wt} \%$ Co (Table 3). Olivine present in the samples contains $0.40 \mathrm{wt} \% \mathrm{NiO}$ and $6.91 \mathrm{wt} \% \mathrm{FeO}$, while serpentine contains $0.18 \mathrm{wt} \% \mathrm{NiO}$ and $3.02 \mathrm{wt} \%$ $\mathrm{FeO}$ (Tzamos, unpublished $\mathrm{PhD}$ thesis). 
Table 1 - Chemical composition (wt \%) of Awaruite (Xerolivado mine serpentinite).

\begin{tabular}{|c|c|c|c|c|c|c|c|}
\hline Sample & D4-5/717A & D4-5/717B & D4-5/738 & C1/745A & C1/745B & C3/717B & Average \\
\hline As & Bdl & 0.03 & Bdl & N/A & N/A & N/A & 0.01 \\
\hline $\mathbf{S b}$ & 0.03 & Bdl & Bdl & N/A & N/A & N/A & 0.01 \\
\hline Co & 0.95 & 1.06 & 1.91 & N/A & N/A & N/A & 1.31 \\
\hline $\mathbf{C u}$ & 1.44 & 3.63 & 1.29 & 0.93 & 1.52 & 0.35 & 1.53 \\
\hline $\mathrm{Fe}$ & 22.17 & 21.45 & 16.38 & 24.74 & 20.18 & 25.10 & 21.67 \\
\hline $\mathbf{N i}$ & 74.65 & 73.42 & 80.13 & 74.76 & 77.52 & 73.76 & 75.71 \\
\hline Total & 99.24 & 99.59 & 99.71 & 100.43 & 99.22 & 99.21 & 100.24 \\
\hline \multicolumn{8}{|c|}{ Structural formulae based on $3(\mathrm{Ni})$} \\
\hline As & - & - & - & - & - & - & - \\
\hline Sb & - & - & - & - & - & - & - \\
\hline Co & 0.04 & 0.04 & 0.07 & 0.00 & 0.00 & 0.00 & 0.03 \\
\hline $\mathbf{C u}$ & 0.05 & 0.14 & 0.04 & 0.03 & 0.05 & 0.01 & 0.06 \\
\hline Fe & 0.94 & 0.92 & 0.64 & 1.04 & 0.82 & 1.07 & 0.91 \\
\hline $\mathbf{N i}$ & 3.00 & 3.00 & 3.00 & 3.00 & 3.00 & 3.00 & 3.00 \\
\hline Total & 4.03 & 4.10 & 3.75 & 4.07 & 3.87 & 4.08 & 4.00 \\
\hline
\end{tabular}

Bdl: Below detection limit, N/A: not analyzed

Table 2 - Chemical composition (wt\%) of Heazlewoodite (Xerolivado mine serpentinite).

\begin{tabular}{|c|c|c|c|c|c|c|c|c|c|}
\hline Sample & $\begin{array}{c}\text { D4- } \\
\text { 5/717A }\end{array}$ & $\begin{array}{c}\text { D4- } \\
\text { 5/717B }\end{array}$ & $\begin{array}{c}\text { D4- } \\
\text { 5/717C }\end{array}$ & $\begin{array}{l}\text { D4/ } \\
765\end{array}$ & $\begin{array}{c}\text { D4- } \\
\text { 5/738A }\end{array}$ & $\begin{array}{c}\text { D4- } \\
\text { 5/738B }\end{array}$ & $\begin{array}{l}\text { C1/ } \\
745\end{array}$ & $\begin{array}{l}\text { C1/ } \\
745\end{array}$ & Average \\
\hline As & Bdl & Bdl & Bdl & Bdl & 0.02 & 0.02 & N/A & N/A & 0.01 \\
\hline Sb & Bdl & Bdl & Bdl & Bdl & 0.04 & Bdl & N/A & N/A & 0.01 \\
\hline Co & 0.06 & 0.14 & 0.12 & 0.04 & 0.27 & 0.10 & N/A & N/A & 0.12 \\
\hline $\mathbf{C u}$ & Bdl & Bdl & Bdl & Bdl & Bdl & Bdl & Bdl & Bdl & Bdl \\
\hline Fe & 1.42 & 1.14 & 2.11 & 1.27 & 1.82 & 1.52 & 1.07 & 1.48 & 1.48 \\
\hline $\mathbf{N i}$ & 72.01 & 70.95 & 70.71 & 70.94 & 70.99 & 71.10 & 72.14 & 71.75 & 71.32 \\
\hline $\mathbf{S}$ & 27.44 & 27.81 & 27.43 & 27.40 & 27.20 & 27.39 & 25.06 & 24.81 & 26.82 \\
\hline Total & 100.93 & 100.04 & 100.37 & 99.65 & 100.34 & 100.13 & 98.27 & 98.04 & 99.76 \\
\hline \multicolumn{10}{|c|}{ Structural formulae based on $2(S)$} \\
\hline As & - & - & - & - & - & - & - & - & - \\
\hline Sb & - & - & - & - & - & - & - & - & - \\
\hline Co & - & 0.01 & - & - & 0.01 & - & - & - & - \\
\hline $\mathbf{C u}$ & - & - & - & - & - & - & - & - & - \\
\hline $\mathbf{F e}$ & 0.06 & 0.05 & 0.09 & 0.05 & 0.08 & 0.06 & 0.05 & 0.07 & 0.06 \\
\hline $\mathrm{Ni}$ & 2.87 & 2.79 & 2.82 & 2.83 & 2.85 & 2.84 & 3.15 & 3.16 & 2.91 \\
\hline $\mathbf{S}$ & 2.00 & 2.00 & 2.00 & 2.00 & 2.00 & 2.00 & 2.00 & 2.00 & 2.00 \\
\hline Total & 4.93 & 4.85 & 4.91 & 4.88 & 4.94 & 4.90 & 5.19 & 5.23 & 4.99 \\
\hline
\end{tabular}

Bdl: Below detection limit, N/A: Not analyzed 
Table 3 - Chemical composition (wt\%) of Pentlandite (Xerolivado mine serpentinite).

\begin{tabular}{|cccccc|}
\hline Sample & D4-5/765A & D4-5/738 & D4/765 & D4-5/765B & Average \\
\hline As & Bdl & Bdl & 0.01 & 0.04 & 0.01 \\
\hline Sb & Bdl & Bdl & Bdl & 0.08 & 0.02 \\
\hline Co & 18.18 & 17.50 & 19.56 & 15.58 & 17.71 \\
\hline Cu & Bdl & 0.02 & Bdl & Bdl & 0.01 \\
\hline Fe & 21.70 & 22.57 & 22.10 & 17.70 & 21.02 \\
\hline Ni & 26.09 & 27.97 & 23.34 & 35.17 & 28.14 \\
\hline S & 33.30 & 31.56 & 34.33 & 30.52 & 32.43 \\
\hline Total & 99.27 & 99.62 & 99.34 & 99.09 & 99.34 \\
\hline & & Structural formulae based on 8 (S) & & \\
\hline As & - & - & - & - & - \\
\hline Sb & - & - & - & 0.01 & - \\
\hline Co & 2.38 & 2.41 & 2.48 & 2.22 & 2.38 \\
\hline Cu & - & - & - & - & - \\
\hline Fe & 2.99 & 3.28 & 2.96 & 2.66 & 2.98 \\
\hline Ni & 3.42 & 3.87 & 2.97 & 5.03 & 3.79 \\
\hline S & 8.00 & 8.00 & 8.00 & 8.00 & 8.00 \\
\hline Total & 16.79 & 17.56 & 16.41 & 17.92 & 17.15 \\
\hline Bel & & & & \\
\hline
\end{tabular}

Bdl: Below detection limit

\section{Discussion and conclusions}

The chemical formulae of the studied opaque minerals are $\mathrm{Fe}_{0.91} \mathrm{Cu}_{0.06} \mathrm{Co}_{0.03} \mathrm{Ni}_{3}$ for awaruite, $\mathrm{Ni}_{2.91} \mathrm{Fe}_{0.06} \mathrm{~S}_{2}$ for heazlewoodite and $\mathrm{Ni}_{3.79} \mathrm{Fe}_{2.98} \mathrm{Co}_{2.38} \mathrm{~S}_{8}$ for Co-pentlandite. In figures 4 and 5, the relative compositions of the studied mineral phases in $\mathrm{Fe}-(\mathrm{Ni}+\mathrm{Co})-\mathrm{S}$ and $\mathrm{Fe}-\mathrm{Ni}-\mathrm{Co}$ are shown respectively.

The formation of heazlewoodite, awaruite and magnetite as a result of the serpentinization is clearly shown by the rock texture, with disseminated small grains of the opaque minerals in the serpentinite, with the formation of rims of heazlewoodite (Fig. 3c) and awaruite (Fig. 3b) around Co-pentlandite and by even more severe substitution of Co-pentlandite grains from awaruite (Fig. 3d).

Nickel was contained in the original $\mathrm{Mg}-\mathrm{Fe}$ olivine and the primary Co-pentlandite. The initial chemical composition of the $(\mathrm{Mg}, \mathrm{Fe}, \mathrm{Ni})$ olivine, the reducing environment during serpentinization, the oxygen and sulfur fugacity ( $\mathrm{fO}_{2}$ and $\mathrm{fS}_{2}$ ), controlled the formation and chemical composition of the heazlewoodite and the Ni-Fe alloy (awaruite). Heazlewoodite is a product of the primary Copentlandite reduction, resulting from the serpentinization of the ultramafic rock which contained traces of pentlandite (Craig and Scott, 1974; Brown, 1980; Filippidis and Annersten, 1981; Annersten et al., 1982; Filippidis, 1982, 1985, 1991; Nord et al., 1982; Deer et al., 1997).

The serpentinization of $(\mathrm{Mg}, \mathrm{Fe}, \mathrm{Ni})$ olivine and the alteration of primary Co-pentlandite, converted some of $\mathrm{Ni}$ and $\mathrm{Fe}$ into the serpentine, and some of $\mathrm{Ni}, \mathrm{Fe}$ and $\mathrm{Co}$ into heazlewoodite and awaruite. At very low sulfur and oxygen fugacity to sulfur and oxygen free serpentinization system, awaruite and heazlewoodite were formed. Heazlewoodite, awaruite and magnetite were formed as a result of the serpentine and brucite being unable to incorporate as much $\mathrm{Fe}$ and $\mathrm{Ni}$ into their lattices as the original olivine. The $\mathrm{Ni}$ content of awaruite is derived both from primary olivine and from primary Co-pentlandite. The reducing environment resulting from serpentinization yields a low sulphur fugacity, which favour the formation of the reduced opaque assemblage heazlewoodite-awaruitemagnetite. 


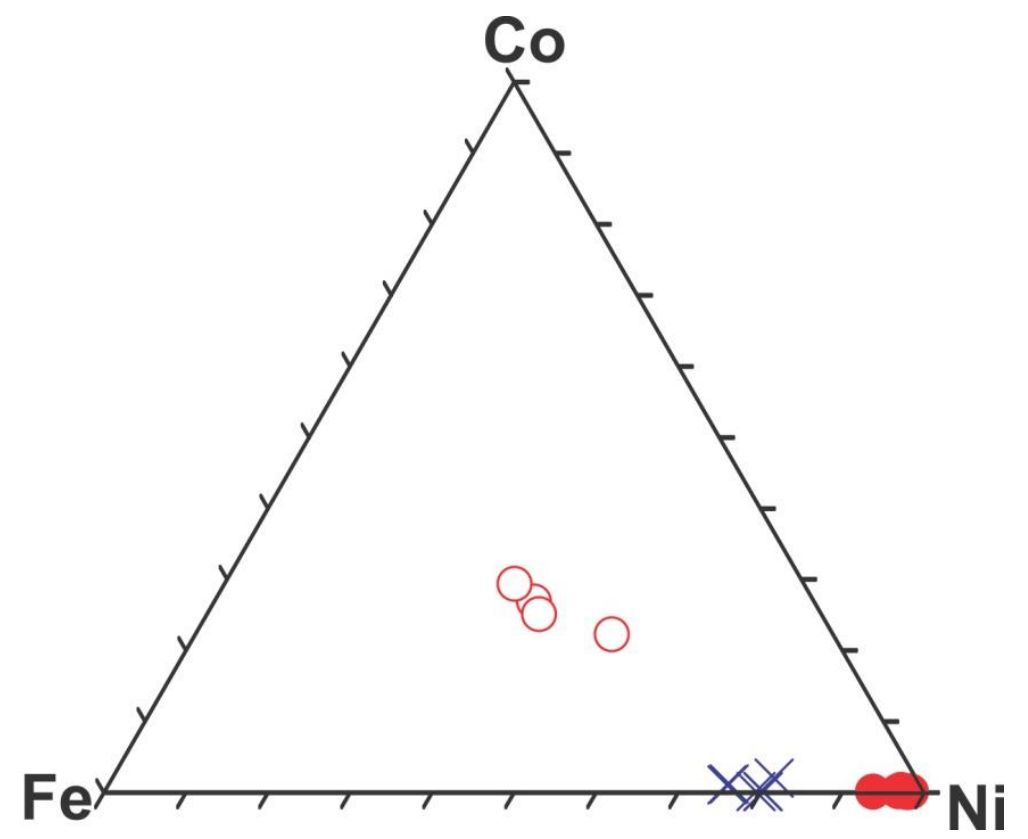

Figure 4 - Ternary diagram $\mathrm{Fe}-(\mathrm{Ni}+\mathrm{Co})-\mathrm{S}$ showing the relative compositions of the Xerolivado mine pentlandites (o), heazlewoodites $(\bullet)$ and awaruites (x).

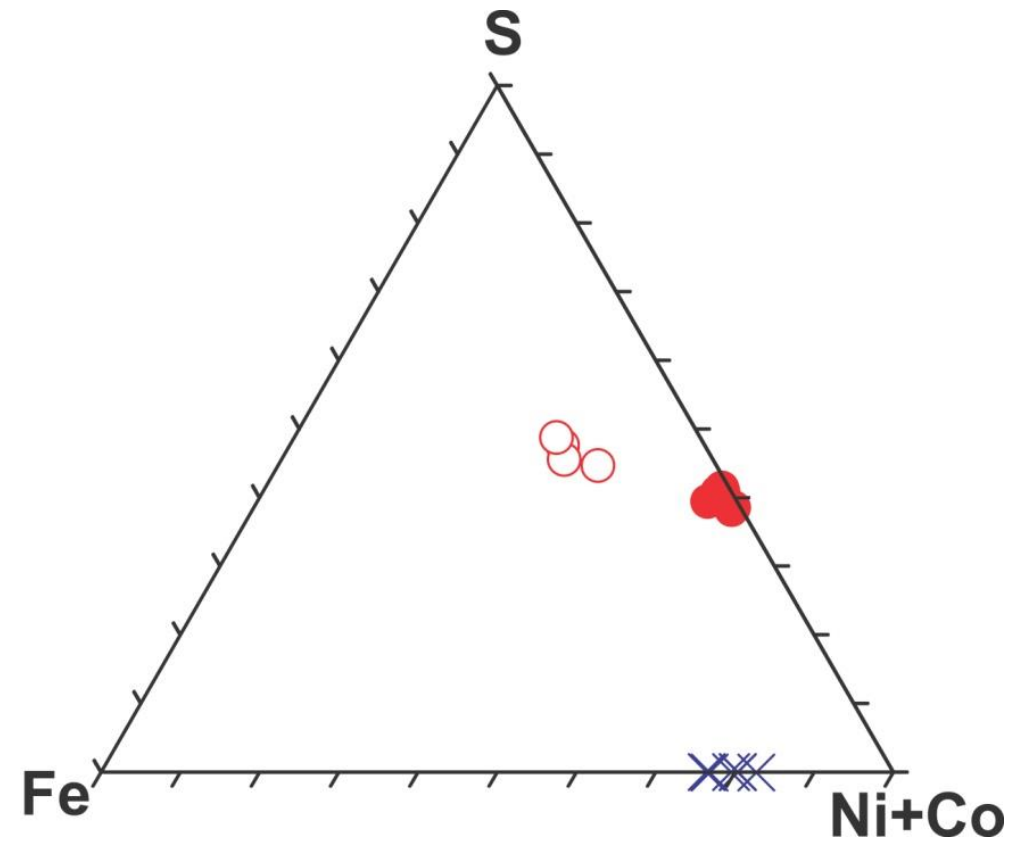

Figure 5 - Ternary diagram Fe-Ni-Co showing the relative compositions of the Xerolivado mine pentlandites $(0)$, heazlewoodites $(\bullet)$ and awaruites $(\mathbf{x})$.

\section{Aknowledgments}

E. Tzamos would like to thank the Greek State Scholarship Foundation (IKY) for partly financing his $\mathrm{PhD}$ research, a part of which is presented in this paper. Andrea Risplendente from University of Milan is thanked for helping with the micro-analyses. 


\section{References}

Annersten, H., Ericsson, T. and Filippidis, A., 1982. Cation ordering in Ni-Fe olivines, Amer. Miner., 67, 1212-1217.

Apostolidis, G., Mastoris, K. and Vgenopoulos, A.G., 1981. Exploration of the Xerolivado-chromite deposits and their chemical, mineralogical and physical properties, Proc. of the Intern. Symp. Metallogeny of Mafic and Ultramafic complexes, 9-11 Oct.1980 Athens, 1, 1-20.

Ashley, P. M., 1973. Pedogenesis of sulphide bearing reaction zones in the Coolac ultramafic belt, New South Wales, Australia, Mineral. Depos., 8, 370-378.

Beccaluva, L., Ohnenstetter, D., Ohnenstetter, M. and Paupy, A., 1984. Two magmatic series with island arc affinities within the Vourinos ophiolite, Contrib. Mineral. Petrol., 85, 253-271.

Bortolotti, V., Chiari, M., Marcucci, M., Marroni, M., Pandolfi, L., Principi, G. and Saccani, E., 2004. Comparison among the Albanian and Greek ophiolites; in search of constraints for the evolution of the Mesozoic Tethys Ocean, Ofioliti, 29, 19-35

Brown, G.E.Jr., 1980. Olivines, In: Ribbe, P.H., ed., Orthosilicates, Miner. Soc. America, Washington D.C. Reviews in Mineralogy, 5, 275-381.

Craig, J.R. and Scott, S.D., 1974. Sulfide phase equilibria, In: Ribbe, P.H., ed., Sulfide Mineralogy, Miner. Soc. America, 1, CS1-110.

Deer, W.A., Howie, R.A. and Zussman, J., 1997. Orthosilicates. Rock-forming minerals vol. 1A, The Geol. Soc., London, 919 pp.

Donaldson, M.J., 1981. Redistribution of ore elements during serpentinization and talc-carbonate alteration of some Archean dunites, Western Australia, Econ. Geol., 76, 1698-1713.

Donaldson, M.J. and Bromley, G.J., 1981. The Honeymoon well nickel sulfide deposits, western Australia, Econ. Geol., 76, 1550-1564.

Filippidis, A., 1982. Experimental study of the serpentinization of $\mathrm{Mg}-\mathrm{Fe}-\mathrm{Ni}$ olivine in the presence of sulphur, Can. Miner., 20, 567-574.

Filippidis, A., 1985. Formation of awaruite in the system Ni-Fe-Mg-Si-O-H-S and olivine hydration with $\mathrm{NaOH}$ solution: An experimental study, Econ. Geol., 80, 1974-1980.

Filippidis, A., 1991. Further comments on the opaque mineral assemblages in ultramafic rocks: an experimental study, Ofioliti, 16, 1-6.

Filippidis, A., 1996. Chemical variation of olivine in the serpentinite of the central section in the Xerolivado chrome mine of Vourinos, Greece, N. Jb Miner. Mh., 170(2), 189-205.

Filippidis, A., 1997. Chemical variation of chromite in the central sector of Xerolivado chrome nine of Vourinos, western Macedonia, Greece, N. Jb Miner. Mh., 354-370.

Filippidis, A. and Annersten, H., 1981. Mineral chemical investigation of an ultramafic nickel bearing body in the Swedish Caledonides, Proc. of the Intern. Symp. Metallogeny of Mafic and Ultramafic complexes, 9-11 Oct.1980 Athens, 2, 115-130.

Grieco, G. and Merlini, A., 2012. Chromite alteration processes within Vourinos ophiolite, Int. J. Earth Sci., 101(6), 1523-1533.

Grivas, E., Rassios, A., Konstantopoulou, G., Vacondios, I. and Vrahatis, G., 1993. Drilling for "blind" podiform chrome orebodies at Voidolakkos in the Vourinos ophiolite complex Greece, Econ. Geol., 88(2), 461-468.

Groves, D.I. and Keays, R.R., 1979. Mobilization of ore-forming elements during alteration of dunites, Mt. Keith-Betheno, Western Australia, Can. Mineral., 17, 373-389.

Groves, D.I., Barret, F.M. and McQueen, K.G., 1979. The relative roles of magmatic segragation, volcanic exhalation and regional metamorphism in the generation of volcanic associated nickel ores of Western Australia, Can. Mineral., 17, 319-336.

Harkins, M.E., Green, H.W. and Moores, E.M., 1980. Multiple intrusive events documented from the Vourinos complex, Northern Greece, Amer. J. Sci., 280A, 284-295.

Jackson, E.D., Green, H.W. and Moores, E.M., 1975. The Vourinos ophiolite, Greece: cyclic unit of lineated cumulates overlying harzburgite tectonite, Geol. Soc. America Bull., 86, 390-398. 
Kanehira, K., Banno, S. and Yui, S., 1975. Awaruite, heazlewoodite, am native copper in serpentinized peridotite from the Mineoka district southern Boso Peninsula, J. Japan, Assoc. Mineral. Petrol. Econ. Geol., 70, 388-394.

Konstantopoulou, G., 1993. Structural criteria in locating chromite ores: evidence from the Rizo district, Vourinos ophiolite, Greece, Bull. Geol. Soc. Greece, 28, 381-392.

Konstantopoulou, G. and Economou-Eliopoulos, M., 1991. Geochemistry of the Vourinos chromite ores, Greece. In: Malpas, J., Moores, E., Panayiotou, A. and Xenophontos, C., eds, Ophiolites, Oceanic Crustal Analogues, Proc. Symp. "Troodos 1987", Nicosia, Cyprus, 605-613.

Krishna Rao, J.S.R., 1964. Native nickel-iron alloy, its mode of occurrence, distribution and origin, Econ. Geol., 59, 443- 448.

Liati, A., Gebauer, D. and Fanning, C.M., 2004. The age of ophiolitic rocks of the Hellenides (Vourins, Pindos, Crete): first U-Pb ion microprobe (SHRIMP) zircon ages, Chem. Geol., 207(3-4), 171-188.

Margaras, S. and Vacondios, I., 1996. Metallogenic map of the Vourinos ophiolite complex (West Macedonia, Greece), IGME, Greece.

Moores, E.M., 1969. Petrology and structure of the Vourino ophiolite complex of Northern Greece, Geol. Soc. America, Special Paper, 118, 1-74.

Nord, A.G., Annersten, H. And Filippidis, A., 1982. The cation distribution in synthetic Mg-Fe-Ni olivines, Amer. Miner., 67, 1206-1211.

Paraskevopoulos, G. and Economou, M., 1986. Genesis of magnetite ore occurrences by metasomatism of Chromite ores in Greece, N. Jb. Miner. Abh., 140, $29-53$.

Pasteris, J.D., 1984. Further interpretation of the Cu-Fe-Ni sulfide mineralization in the Duluth Complex, norteastern Minnesota, Can. Miner., 22, 39-53.

Rassios, A. and Kostopoulos, D., 1990. The geochemistry of dunite and its relation to the position of chromitites in the Vourinos ophiolite complex, Greece, In: Malpas, J., Moores, E., Panayiotou, A. and Xenophontos, C., eds, Ophiolites, Oceanic Crustal Analogues. Proc. Symp. "Troodos 1987", Nicosia, Cyprus, 593-604.

Rassios, A.H.E. and Moores, E.M., 2006. Heterogeneous mantle complex, crustal processes, and obduction kinematics in a unified Pindos-Vourinos ophiolitic slab (northern Greece), Geol. Soc., London, Special Publ., 260, 237-266.

Roberts, S., 1988. Ophiolite chromite formation: a marginal basin phenomenon?, Econ. Geol., 83, 1034-1036.

Ross, R., Mercier, J., Ave Lallemant, H., Carter, N. and Zimmerman, J., 1980. The Vourinos ophiolite complex, Greece: the tectonite suite, Tectonophysics, 70, 63-83.

Saccani, E., Beccaluva, L., Coltorti, M., Siena, F., 2004. Petrogenesis and tectono-magmatic significance of the Albanide-Hellenide subpelagonian ophiolites, Ofioliti, 29, 75-93

Seccombe, P.K., Groves, D.I., Marston, R.J. and Barrett, E.M., 1981. Sulfide paragenesis and sulfur mobility in Fe-Ni-Cu sulfide ores at Lunnon and Juan Main shoots, Kambalda: textural and Sulfur isotopic evidence, Econ. Geol., 76, 1675-1685.

Shima, H. and Naldrett, A.J., 1975. Solubility of sulfur in an ultramafic melt and the relevance of the system Fe-S-O, Econ. Geol., 70, 960-967.

Stamoulis, K., 1990. Observations on the formation of the chromitite bodies of the Xerolivado mine (in Greek), EL.SI. S.A., Unpubl. internal report, 184 pp. 